\title{
ANALISA HASIL PENERIMAAN PENGGUNA TERHADAP APLIKASI KARTU UNDANGAN PERNIKAHAN BERBASIS AUGMENTED REALITY
}

\author{
Muhammad Abdullah Muthik ${ }^{1}$, Rizkysari Mei Maharani ${ }^{2}$, Anastasya Latubessy ${ }^{3}$ \\ ${ }^{1}$ Teknik Informatika Fakultas Teknik Universitas Muria Kudus \\ ${ }^{2}$ Teknik Informatika Fakultas Teknik Universitas Muria Kudus \\ ${ }^{3}$ Teknik Informatika Fakultas Teknik Universitas Muria Kudus \\ Email: ${ }^{1}$ muthikres86@gmail.com, ${ }^{2}$ rizky.sari@umk.ac.id, ${ }^{3}$ anastasya.latubessy@umk.ac.id
}

(Naskah masuk: 8 Juni 2020, diterima untuk diterbitkan: 15 Juni 2020)

\begin{abstract}
Abstrak
Sebuah aplikasi yang baik perlu mendapat tanggapan penilaian yang baik, oleh sebab itu penelitian ini dilakukan untuk mengetahui tingkat kevalidan dan mengetahui respon pengguna dari aplikasi kartu undangan pernikahan berbasis Augmented Rality. Metode yang dilakukan untuk penelitian ini menggunakan metode $M D L C$ (Multimedia Develomen Live Cycle) yang terdiri dari 6 tahapan yaitu: Pengonsepan, perancangan, pengumpulan bahan, pembutan, pengujian dan penditribusian. Sementara untuk survey reponden menggunakan sepuluh pernyataan dengan interval skala Likert. Dari hasil penelitian yang dilakukan oleh 30 responden mendapatkan hasil yang memuaskan dan sesuai dengan harapan pengguna
\end{abstract}

Kata kunci: Kartu Undangan, Augmented Reality, MDLC

\section{ANALYSIS OF USER ACCEPTANCE RESULTS ON APPLICATION WEDDING INVITATION OF AUGMENTED REALITY}

\begin{abstract}
The purpose of this study was to determine the level of validity and determine the response of the application of wedding invitation cards based on Augmented Rality. The method used for this research uses the MDLC (Multimedia Develomen Live Cycle) method which consists of 6 stages: Conceptualization, design, material collection, pembutan, testing and distribution. From the results of research conducted by 30 respondents get satisfactory results and in accordance with user expectations
\end{abstract}

Keywords: Wedding Invitation, Augmented Reality, $M D L C$

\section{PENDAHULUAN}

Sering dengan kemajuan teknologi yang berkembang banyak cara yang dilakukan untuk membuat sebuah media undangan terbaru salah satu teknologi yang sedang berkembang dan mulai banyak digunakan adalah Augmented Reality.

Menurut (Azuma, 1997), augmented reality adalah menggabungakan dunia nyata dan virtual, bersifat interaktif secara real time, dan merupakan animasi 3D. Tidak seperti realitas maya yang sepenuhnya menggantikan kenyataan, realitas tertambah sekedar menambahkan atau melengkapi kenyataan. Benda-benda maya menampilkan informasi yang tidak dapat diterima oleh pengguna dengan inderanya sendiri. Hal ini membuat realitas tertambah sesuai sebagai alat untuk membantu persepsi dan interaksi penggunanya dengan dunia nyata. Informasi yang ditampilkan oleh benda maya membantu pengguna melaksanakan kegiatankegiatan dalam dunia nyata.

Dalam penelitian ini penulis menggunakan metode MDLC (Multimedia Develomen Live Cycle). Proses pembangunan dari model MDLC ini terdeiri dari 6 proses yaitu: Pengonsepan, perancangan, pengumpulan bahan, pembutan, pengujian dan penditribusian. Untuk pengujian aplikasi ini menggunakan pengujian blacbox testing, whitebox testing, dan pengujian oleh pengguna. Blacbox texting di dilakukan dengan tujuan untuk menguji kebenaran proses aplikasi berjalan. Pengujian whitebox testing dilakukan untuk mengetahui cara kerja suatu prangkat lunak secara internal.

Pengujian oleh pengguna dilakukan oleh 30 responden untuk mengisi kuisoner tentang penilain aplikasi. Pengujian ini dilakukan untuk mengetahui sejauh mana system dapat memenuhi kebutuhan 
ketika digunakan dalam proses undangan augmented reality ini. Dalam kuisoner ini terdapat indicator penilaian dari segi tampilan aplikasi, fleksibilitas, efisiensi, dan efektifitas.

Hasil akhir dari penelitian ini adalah mengukur fungsi system yaitu aplikasi UndanagnAR berbasis android untuk mengetahui kemapuan aplikasi merespon dengan menggunakan smartphone yang berbeda

\section{METODOLOGI PENELITIAN}

Pendekatan penelitian yang dilakukan pada penelitian ini adalah metode MDLC (Multimedia Developmen Life Cycle) Binanto, 2010. Proses pengembangan dari model MDLC terdiri dari 6 tahapan yaitu:

a. Concept (pengonsepan)
Tahapan kita menemukan tujuan, termasuk identifikasi audiens, jenis aplikasi (presentasi, interaksi, dan lain-lain). Tujuan aplikasi (informasi, hiburan, latihan ,dan lainlain), dan spesifikasi umum. Dasar aturan untuk perancangan juga ditentukan pada tahap ini, seperti ukuran aplikasi target, dan lain-lain.

b. Design (perancangan)

Pada tahap ini biasanya menggunakan story board untuk menggambarkan deskripsi tiap scene, dengan menggunakan semua objek multimedia, tautan scene lainnya dan bagian alir (Flowchart) untuk menggambarkan alir dari satu scene ke scene lain.

c. Material Collecting (pengumpulan bahan)

Tahapan ini merupakan tahapan pengumpulan bahan sesuai dengan kebutuhan pengembangan multimedia yang dikerjakan.

d. Assembly (pembuatan)

Tahapan assamble (pembuatan) adalah tahap pembuatan semua objek atau bahan multimedia. Pembuatan aplikasi didasarkan pada tahap desain seperti stroryboard, bagan alir, dan/atau struktur navigasi

e. Testing (pengujian)

Tahap testing dilakukan setelah selesai tahap pembuatan dan seluruh animasi yang telah dibuat maka akan dilakukan pengujian, dalam tahap testing ini menggunakan alpha dan beta. Salah satu hal yang harus diutamakan dalam pembuatan animasi adalah harus berjalan baik dengan lingkungan user.

f. Distribution (pendistribusian)

Pada tahap ini, aplikasi serta semua informasi yang ada dimasukkan ke dalam sebuah library, pada tahap ini juga merupakan tahap dimana implementasi serta evaluasi terhadap suatu produk multimedia secara detail. (Binanto, 2010)

Penulis melakukan pengujian menggunakan kuisoner. Pengujian ini berupa pertanyaan memalui google form yang disi oleh 30 resonden. Pada kuisoner ini terdapat 10 buah pertanyaan seperti yang di tunjukan pada Table 1 di bawah ini.

Table 1. Daftar Pertanyaan

\begin{tabular}{|c|c|c|c|c|c|c|}
\hline \multirow[t]{2}{*}{ NO } & \multirow[t]{2}{*}{ PERTANYAAN } & \multicolumn{5}{|c|}{ NILAI } \\
\hline & & 1 & 2 & 3 & 4 & 5 \\
\hline 1 & $\begin{array}{l}\text { Apakah informasi yang } \\
\text { disediakan oleh aplikasi } \\
\text { ini mudah dimengerti? }\end{array}$ & & & & & \\
\hline 2 & $\begin{array}{l}\text { Apakah penggunaan } \\
\text { menu ataau fitur } \\
\text { aplikasi menu mudah } \\
\text { digunakan? }\end{array}$ & & & & & \\
\hline 3 & $\begin{array}{l}\text { Secara keseluruhan } \\
\text { apakah aplikasi ini } \\
\text { memuaskan? }\end{array}$ & & & & & \\
\hline 4 & $\begin{array}{l}\text { Apakah aplikasi nyaman } \\
\text { di gunakan? }\end{array}$ & & & & & \\
\hline 5 & $\begin{array}{l}\text { Apakah aplikasi ini } \\
\text { sesuai dengan } \\
\text { kebutuhan? }\end{array}$ & & & & & \\
\hline 6 & $\begin{array}{l}\text { Apakah aplikasi mudah } \\
\text { dipelajari? }\end{array}$ & & & & & \\
\hline 7. & $\begin{array}{l}\text { Apakah aplikasi mudah } \\
\text { di oprasikan? }\end{array}$ & & & & & \\
\hline 8. & $\begin{array}{l}\text { Apakah aplikasi } \\
\text { bermanfaat bagi } \\
\text { pengguna? }\end{array}$ & & & & & \\
\hline 9. & $\begin{array}{l}\text { Apakah tampilan menu } \\
\text { dalam aplikasi mudah } \\
\text { untuk dikenali? }\end{array}$ & & & & & \\
\hline 10. & $\begin{array}{l}\text { Apakah aplikasi } \\
\text { memppunyai } \\
\text { kemampuan dan fungsi } \\
\text { sesuai yang diharapkan? }\end{array}$ & & & & & \\
\hline
\end{tabular}

Pada Table 1 menjelakan tentang Daftar pertanyaan yang akan diisi oleh resonden. Kuisoner memiliki 10 indikator petanyaan dengan 5 penilaian

Pada pengujian ini, analisis data kriteria penilaian menggunakan skala Likert dengan memberikan lima pilihan jawaban seperti yang di tunjukan pada Table 2

Table 2. Interval Skala Likert Pernyataan Positif

\begin{tabular}{cc}
\hline Alternatif Jawaban & Nilai \\
\hline Sangat Tidak Setuju & 1 \\
Tidak Setuju & 2 \\
Netral & 3 \\
Setuju & 4 \\
Sangant Setuju & 5 \\
\hline
\end{tabular}

Pada Table 2 mentelakan tentang skala Likert dengan 5 ilihan yaitu sangan tidak setuju, tidak setuju, netral, setuju, sangan setuju.

Kemudian setelah mendapatkan jumlah skor dihitung persentase kelayakan sebagai berikut:

Persentase Kelayakan $(\%)=\frac{\text { Skor yang diobservast }}{\text { Skor yang diharapkan }} \times 100 \%$ 


\section{HASIL DAN PEMBAHASAN}

Pengujian terakhir dilakukan oleh pengguna. Uji lapangan dilakukan oleh 30 responden. Responden mengisi kuisoner tentang penilaina Augmented Reality Undangan melalui google form. Berikut hasil rekap grafik kuisoner pengujian dapat dilihat digambar bawah ini.

\section{Apakah informasi yang disediakan oleh aplikas i ini mudah dimengerti?}

30 tangogapan

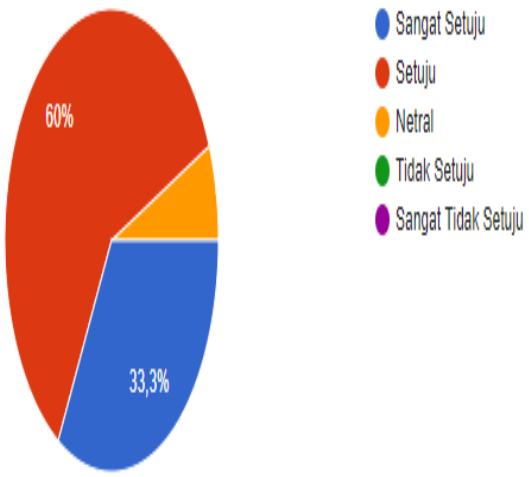

Gambar 1. Grafik kuisoner pertanyaan pertama

Berdasrkan Gambar 1 menjelaskan bahwa, pertanyaan Apakah informasi yang disediakan oleh aplikasi mudah dimengerti? Memperoleh hasil $33,3 \%$ sangat setuju dengan 10 responden pemilih, $60 \%$ setuju dengan 18 responden pemilih, dan $6,7 \%$ netral dengan 2 responden pemilih.

\section{Apakah penggunaan menu ataufturu aplikasi menu mudah digunakan?}

\section{0 tangogapan}

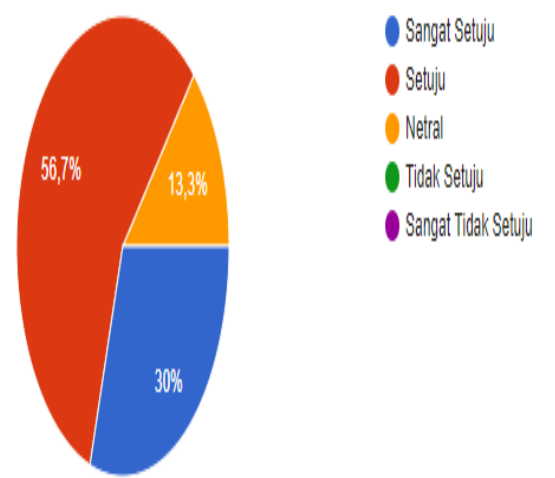

Gambar 2. Grafik Kuisoner pertanyaan Kedua

Berdasarkan Gambar 2 menjelaskan bahwa pertanyaan, apakah penggunaan menu atau fitur apliksi menu mudah digunakan?. Memperoleh hasil $30 \%$ sangat setuju dengan 9 responden pemilih, $56,7 \%$ setuju dengan 17 responden pemilih, dan $13,3 \%$ netral dengan 4 responden pemilih.
Secara keseluruhan apakkah aplikas i in memuaskan?

30 tanggapan

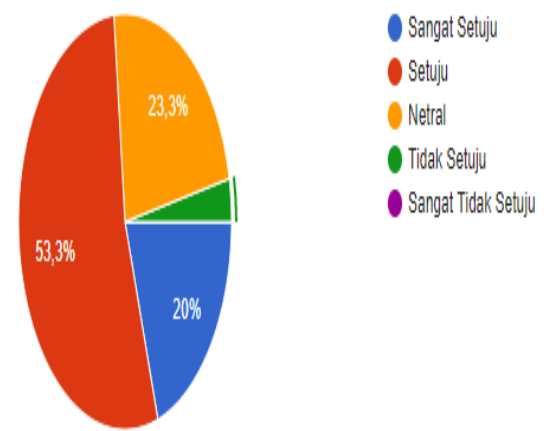

Gambar 3. Grafik Kuisoner Pertanyaan Ketiga

Berdasarkan Gabar 3 menjelaskan bahwa, pertanyaan, secara keseluruhan apakah aplikasi ini memuaskan?. Memperoleh hasil 20\% sangat setuju dengan 6 responden pemilih, 53,3\% setuju dengan 16 responden pemilih, $23,3 \%$ netral dengan 7 responden pemilih, dan 3,3\%.tidak setuju dengan 1responden pemilih.

\section{Apakah aplikasi nyaman di gunakan?}

\section{0 tanggapan}

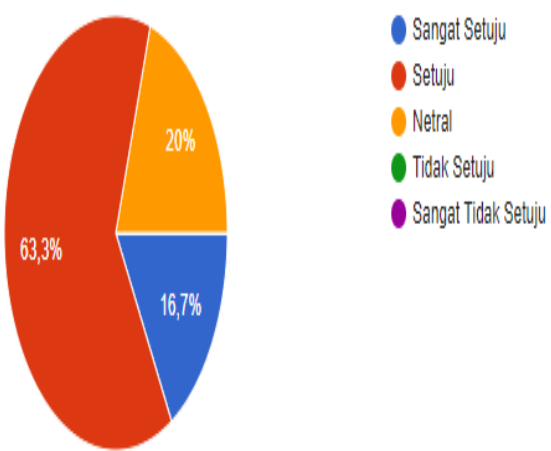

Gambar 4. Grafik Kuisoner pertanyaan Keempat

Berdasrkan Gambar 4 menjelaskan bahwa, pertanyaan, apakah aplikasi nyaman digunakan? Memperoleh hasil 16,7\% sangat setuju dengan 5 responden pemilih, 63,3\% setuju dengan 19 responden pemilih, dan $20 \%$ netral dengan 6 responden pemilih. 


\section{Apakah aplikas ini sesuai dengan kebutuhan?}

30 tanggapan

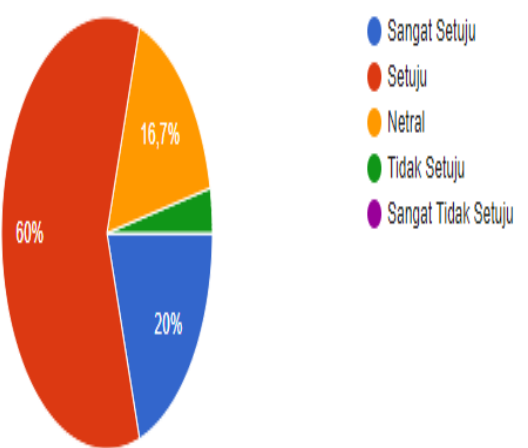

Gambar 5. Grafik Kuisoner pertanyaan Kelima

Berdasrkan Gambar 5 menjelaskan bahwa, pertanyaan, apakah aplikasi ini sesuai dengan kebutuhan? Memperoleh hasil 20\% sangat setuju dengan 6 responden pemilih, $60 \%$ setuju dengan 18 responden pemilih, $16,7 \%$ netral dengan 5 responden pemilih, dan 3,3\% tidak setuju dengan 1 responden pemilih.

\section{Apakah apilikasi mudah dipelajari?}

30 tanggapan

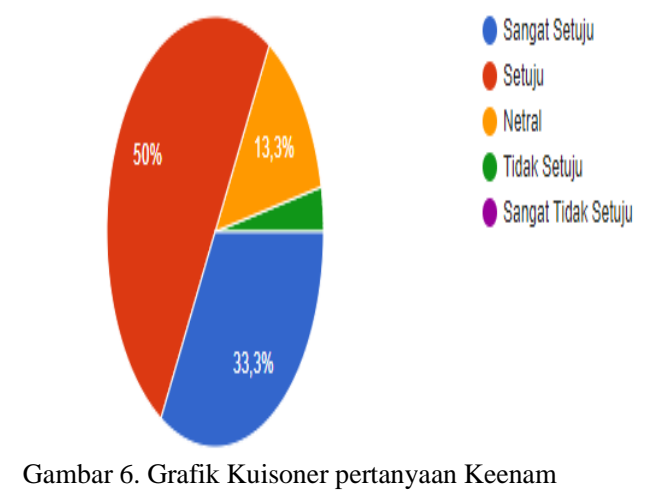

Berdasrkan Gambar 6 menjelaskan bahwa, pertanyaan, apakah aplikasi mudah dipelajari? Memperoleh hasil 33,3\% sangat setuju dengan 10 responden pemilih, $50 \% \mathrm{~s}$

etuju dengan 15 responden pemilih, 13,3\% netral dengan 4 responden pemilih, dan 3,3\% tidak setuju dengan 1 responden pemilih.

\section{Apakah aplikasi mudah di oprasikan?}

30 tanggapan

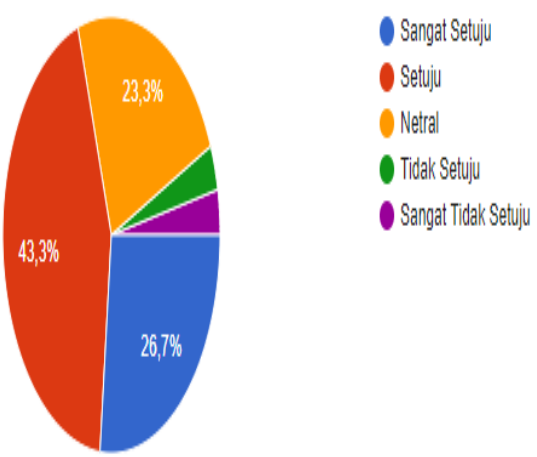

Gambar 7. Grafik Kuisoner pertanyaan Ketuju

Berdasrkan Gambar 7 menjelaskan bahwa, pertanyaan, apakah aplikasi mudah di oprasikan? Memperoleh hasil 26,7\% sangat setuju dengan 8 responden pemilih, 43,3\% setuju dengan 13 responden pemilih, $23,3 \%$ netral dengan 7 responden pemilih, 3,3\% tidak setuju dengan 1 responden pemilih,dan $3,3 \%$ sangat tidak setuju dengan 1 responden pemilih.

\section{Apakah aplikasi bermanfaat bagi pengguna?}

\section{0 tanggapan}

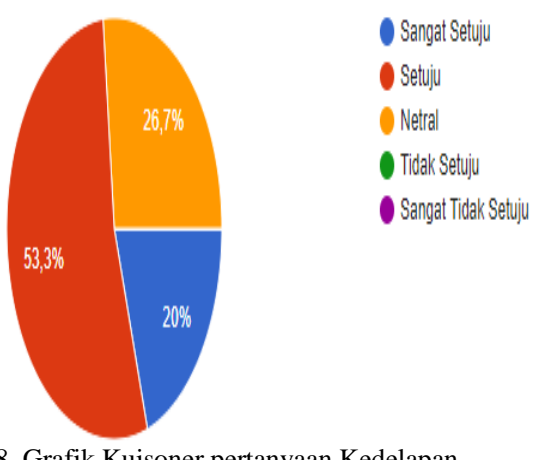

Gambar 8. Grafik Kuisoner pertanyaan Kedelapan

Berdasarkan Gambar 8 menjelaskan bahwa, pertanyaan, apakah aplikasi bermanfaat bagi pengguna? Memperoleh hasil 20\% sangat setuju dengan 6 responden pemilih, 53,3\% setuju dengan 16 responden pemilih, dan $26,7 \%$ netral dengan 8 responden pemilih. 
Apakah tampilan menu dalam apilikasi mudah untuk dikenali?

30 tanggapan

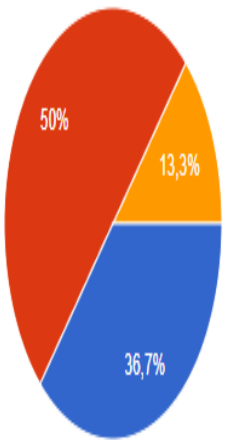

Sangat Setuju

Setuju

Netral

Tidak Setuju

0 Sangat Tidak Setuju

Gambar 9. Grafik Kuisoner pertanyaan Kesembilan

Berdasrkan Gambar 9 menjelaskan bahwa, pertanyaan apakah tampilan menu dalam aplikasi mudah untuk dikenali? Memperoleh hasil 36,7\% sangat setuju dengan 11 responden pemilih, 50\% setuju dengan 15 responden pemilih, dan $13,3 \%$ netral dengan 4 responden pemilih.

\section{Apakah aplikasi mempunyai kemampuan dan fungsi sesuai yang diharapkan?}

30 tanggapan

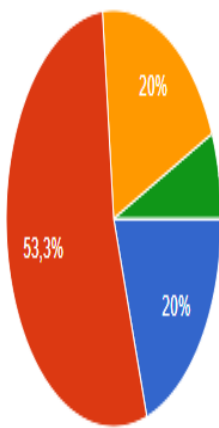

Sangat Setuju

$\checkmark$ Setuju

Netral

Tidak Setuju

O Sangaat Tidak Setuju

$20 \%$

Gambar 10. Grafik Kuisoner pertanyaan Kesepuluh

Berdasrkan Gambar 10 menjelaskan bahwa, pertanyaan, apakah aplikasi mempunyai kemampuan dan fungsi sesuai dengan yang diharapkan? Memperoleh hasil 20\% sangat setuju dengan 6 responden pemilih, 53,3\% setuju dengan 16 responden pemilih, $20 \%$ netral dengan 6 responden pemilih, dan $6,7 \%$ tidak setuju dengan 2 responden pemilih.

Hasil dari jawaban pertanyaan kuisoner kemudian dilakukan diklasifiksikan berdasrkan Tabel 3. Berikut untuk mengetahui kualitas berdasarkan hasil persentase yang di peroleh. $\underline{\text { Tabel 3. Klasifikasi kualitas berdasrkan persentase }}$

\begin{tabular}{c|c}
\hline Persentase & Kategori \\
\hline $0 \%-100 \%$ & Sangat Tinggi \\
$60 \%-79 \%$ & Tinggi \\
$40 \%-59 \%$ & Cukup \\
$20 \%-39 \%$ & Rendah \\
$<20 \%$ & Sangat Rendah \\
\hline
\end{tabular}

Tabel 3 menjelaskan tentang klasifikasi kualitas berdsarkan persentase. Yang natinya di gunakan untuk klasifikasi perindikator.

\begin{tabular}{|c|c|c|}
\hline $\mathrm{No}$ & Pertanyaan & Hasil \\
\hline 1 & $\begin{array}{l}\text { Apakah informasi yang } \\
\text { disediakan oleh aplikasi ini } \\
\text { mudah dimengerti? }\end{array}$ & $85,3 \%$ \\
\hline 2 & $\begin{array}{l}\text { Apakah penggunaan menu } \\
\text { ataau fitur aplikasi menu } \\
\text { mudah digunakan? }\end{array}$ & $83,3 \%$ \\
\hline 3 & $\begin{array}{l}\text { Secara keseluruhan apakah } \\
\text { aplikasi ini memuaskan? }\end{array}$ & $78 \%$ \\
\hline 4 & $\begin{array}{l}\text { Apakah aplikasi nyaman di } \\
\text { gunakan? }\end{array}$ & $79,3 \%$ \\
\hline 5 & $\begin{array}{l}\text { Apakah aplikasi ini sesuai } \\
\text { dengan kebutuhan? }\end{array}$ & $79,3 \%$ \\
\hline 6 & $\begin{array}{l}\text { Apakah aplikasi mudah } \\
\text { dipelajari? }\end{array}$ & $82,6 \%$ \\
\hline 7. & $\begin{array}{l}\text { Apakah aplikasi mudah di } \\
\text { oprasikan? }\end{array}$ & $77,3 \%$ \\
\hline 8. & $\begin{array}{l}\text { Apakah aplikasi bermanfaat } \\
\text { bagi pengguna? }\end{array}$ & $78,6 \%$ \\
\hline 9. & $\begin{array}{l}\text { Apakah tampilan menu } \\
\text { dalam aplikasi mudah untuk } \\
\text { dikenali? }\end{array}$ & $84,6 \%$ \\
\hline 10. & $\begin{array}{l}\text { Apakah aplikasi } \\
\text { memppunyai kemampuan } \\
\text { dan fungsi sesuai yang } \\
\text { diharapkan? }\end{array}$ & $77,3 \%$ \\
\hline
\end{tabular}

Berdasarkan Tabel 4 menjelaskan tentang hasil pengujian memalui kuisoner pada tabel. Di peroleh bahwa aplikasi Augmented Reality Undangan dirancang sudah sesuia dengan harapan pengguna, informasi pada aplikasi Augmented Reality Undangan bermanfaat bagi pengguna.

\section{KESIMPULAN}

Dari hasil uraian yang sudah dipaparkan sebelumnya maka penulis dapat menarik sebuah kesimpulan bahwa perancangan aplikasi Augmented Reality Undangan. dapat memberikan informasi secara menarik. Untuk hasil perindikator pertanyaan adalah P1 memeroleh hail 85,3\%, P2 memperoleh hasil 83,3\%, P3 memperoleh hasil 78\%, P4 memperoleh hasil 79,3\%, P5 memperoleh hasil 79,3\%, P6 memperoleh hasil $82,6 \%$, P7 memperoleh hasil 77,3\%, P8 
32 Indonesian Journal of Technology, Informatics and Science (IJTIS), Vol. 1, No. 2, Juni 2020, hlm. 27-32

memperoleh hasil 78,6\%, P9 memperoleh hasil $84,6 \%$, dan P10 memperoleh hasil 77,3\%.

\section{DAFTAR PUSTAKA}

ALWI, T. (2018). IMPLEMENTASI TEKNOLOGI AUGMENTED REALITY MARKERLES SSEBAGAI MEDIA PENGENALAN HISTORICAL UNIVERSITAS MURIA KUDUS BERBASIS ANDROID (Doctoral dissertation, umk).

ATMOJO, W. T., \& Amelia, M. F. (2018). Pengenalan Perusahaan Berbasis Animasi Pada CV Dhifarindo Global Dengan Metode Multimedia Development Life Cycle. Jurnal Inovasi Informatika, 3(2), 33-42.

AZUMA, R. T. (1997). A survey of augmented reality. Presence: Teleoperators \& Virtual Environments, 6(4), 355-385.

BINANTO, I. (2010). Multimedia Digital Dasar Teori dan Pengembanganya. Yogyakarta: Andi.

FEOH, G., \& Wiryadikara, R. P. (2019, October). PENGUJIAN FUNCTIONAL SUITABILITY PADA IMPLEMENTASI PEMBELAJARAN AKSARA BALI BERBASIS AUGMENTED REALITY. In Seminar Ilmiah Nasional Teknologi, Sains, dan Sosial Humaniora (SINTESA) (Vol. 2, No. 1). 